\title{
An Analysis of Lipoproteins, Bile Acids, and Red Cell Membranes Associated with Target Cells and Spur Cells in Patients with Liver Disease
}

\author{
Richard A. Cooper, Milagros Diloy-Puray, Patricia Lando, and \\ Mortimer S. GreenberG \\ From the Hospital of the University of Pennsylvania, Philadelphia, Pennsylvania \\ 19104, Thorndike Memorial Laboratory, Boston City Hospital, Boston 02118, \\ and Lemuel Shattuck Hospital, Boston, Massachusetts 021.30
}

\begin{abstract}
A B STRACT Most patients with stable cirrhosis of the alcoholic have "target" red cells; however, a minority have "spur" cells and severe hemolytic anemia. These two syndromes were studied in 27 patients with target cells and 17 patients with spur cells, all of whom had advanced cirrhosis. The cholesterol and phospholipid content of red cell membranes effectively distinguished target cells from spur cells. Target cells alone were rich in lecithin, and both the cholesterol/phospholipid and cholesterol/lecithin mole ratios were greater in spur cells. The cholesterol/phospholipid mole ratio of both types of red cells correlated closely with the free cholesterol saturation of serum lipoproteins, as defined by the amount of free cholesterol relative to phospholipid and protein in these lipoproteins. Lecithin: cholesterol acyltransferase (LCAT) activity was decreased in most patients with target cells and spur cells; however, the relationship between this activity and the lipid abnormalities observed was weak. Serum bile acid levels also correlated poorly with serum and cell lipids. However. in patients with target cells the amount of cholic and deoxycholic acids in serum was approximately equal to the amount of chenodeoxycholic acid, whereas in patients with spur cells chenodeoxycholic acid (the precursor of lithocholic acid) predominated.
\end{abstract}

\section{INTRODUCTION}

Anemia is a common complication in patients with cirrhosis of the alcoholic. During the period of active

Dr. Cooper is the recipient of U. S. Public Health Service Career Development Award, 5-K4-AM 38,345.

Received for publication 28 March 1972, and in revised form 2 June 1972. drinking the most common causes of anemia are blood loss, iron deficiency, folic acid deficiency, and suppression of the bone marrow by alcohol (1-6). However, even after therapy for these reversible etiologies, anemia commonly continues. Two syndromes have been well documented in the stable cirrhotic. Most patients have anemia of a mild to moderate degree associated with a moderately decreased red cell life-span and inadequate marrow response (7). The red cells in these patients are frequently targeted in appearance, and spherocytes. presumably the result of splenic pooling, are usually seen as well. Over the past $5 \mathrm{yr}$, a syndrome occurring in patients with cirrhosis of the alcoholic characterized by severe anemia, marked hemolysis, and a red cell morphologic abnormality termed spur cells has been well delineated (8-10). Patients with spur cells tend to have far advanced liver diseases; however, they represent a minority among patients with severe hepatic dysfunction. Why some patients with severe hepatocellular dysfunction develop spur cells and others target cells is poorly understood.

Both spur cells and target cells are acquired characteristics of mature red cells in vivo (8-12) and both have been reproduced in vitro $(8,10,12)$. Two differences in addition to morphology have been obsrved which distinguish these cell types: First, transition to target cells does not impair cellular deformability; however, the transition to spur cells causes a decrease in the the ability of red cells to deform $(10,13)$. Second, although in both cell types membrane lipid increases, it appears that free cholesterol is the predominant lipid acquired in spur cells $(10,14)$ whereas both free cholesterol and phospholipid are usually acquired in target cells $(12.15,16)$. 
Mechanisms of lipid acquisition by red cells in these disorders have not been fully defined. Several relationships suggest themselves: First, red cell membrane lipids exchange, in part, with lipids carried by serum lipoproteins $(17,18)$. Although it is known that patients with liver disease may have abnormalities of their serum lipoproteins $(19,20)$, the role of abnormal lipoproteins in the genesis of the red cell lipid abnormalities is unclear. Second, the serum enzyme lecithin: cholesterol acyltransferase (LCAT) ${ }^{1}$ appears to serve an important role in the metabolism of serum-free cholesterol and lecithin (21). Patients who congenitally lack this enzyme have target-shaped red cells rich in cholesterol and lecithin (22). Since this enzyme deficiency exists in many patients with liver disease it has been proposed that LCAT may play a role in the red cell lipid abnormalities observed in cirrhosis $(12,23-25)$. Third, bile acids have been shown to influence membrane lipid composition under experimental conditions in vitro (12) and in vivo (26). Patients with cirrhosis have abnormalities of bile acid metabolism $(27,28)$ and it has been suggested that these abnormalities may play a role in the genesis of target (12) and spur cells (10). This study was undertaken $(a)$ to quantitate the lipids of spur cells and compare them with the lipids of target cells from patients with comparable degrees of hepatocellular dysfunction, $(b)$ to assess the activity of the serum enzyme LCAT in patients with spur cells and target cells and $(c)$ to characterize the serum lipoproteins, and $(d)$ to characterize the bile acids in these patients.

\section{METHODS}

Patient selection. All patients studied were in the convalescent phase of hospitalization at either the Boston City Hospital or the Lemuel Shattuck Hospital. All had severe liver disease presumed by history, but not in each case established by biopsy, to be cirrhosis of the alcoholic. $\mathrm{Pa}$ tients with spur cells were so designated if they had greater than $20 \%$ of these abnormally spiculated red cells on a Wright's stained peripheral blood smear. Red cells were considered to be spurred if they had multiple, irregular, asymmetrically placed projections confined to the periphery of the cell, as described previously $(8,9)$. They were distinguished by this means from regularly scalloped, crenated (or "burred") red cells. However they were indistinguishable on morphologic grounds from acanthocytes occurring in patients with congenital abetalipoproteinemia. The term spur cell is used rather than acanthocyte in the present study because of differences that exist in the membrane lipid composition of these abnormally shaped cells as they exist in

${ }^{1}$ Abbreviations used in this paper: $\mathrm{BHT}, 2,3$-di-tert-butyl4-methyl-phenol; FC/PL, free cholesterol/phospholipid mole ratio; (FC/Prot), free cholesterol/protein weight ratio; HDL, high density lipoprotein; LCAT, lecithin: cholesterol acyltransferase; LDL, low density lipoprotein; (PL/Prot), phospholipid/protein weight ratio; TLC, thin-layer chromatography; VLDL, very low density lipoprotein.

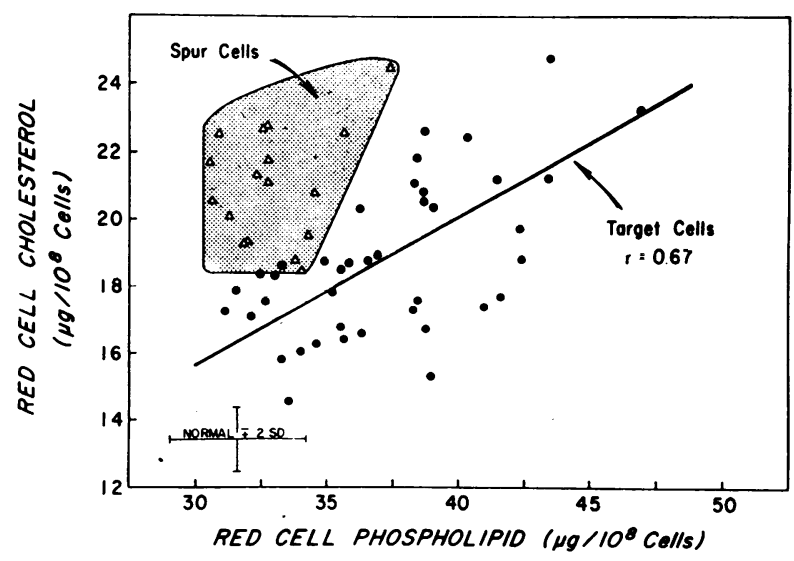

FIGURE 1 The cholesterol and phospholipid content of target and spur cells. Included are data from 17 patients with spur cells and 27 patients with target cells studied in detail and an additional 13 patients with cirrhosis and target cells. The regression analysis calculated for target cells $(y=2.5$ $+0.44 x)$ was significant $(P<0.01)$.

liver disease and abetalipoproteinemia. The presence of spiculated red cells was verified by examination of fresh wet preparations using phase microscopy. Patients considered to have target cells often had occasional spiculated red cells on their peripheral blood smears; however, target cells were infrequent or absent on smears containing predominantly spur cells. In patients without spur cells the per cent target cells varied widely and it was not used as a criterion. Because from our previous studies it was realized that patients with cirrhosis of the alcoholic and spur cells generally had very severe hepatocellular disease, patients with target cells were accepted for study only if they had either ascites or jaundice. One-fourth of these patients manifested varying degrees of hepatic encephalopathy. Studies were carried out in 27 patients with target cells and 17 patients with spur cells. 41 patients were receiving neomycin at the time of study and 3 had received neomycin in the recent past. Not all studies were carried out in each patient. Red cell cholesterol and phospholipid were measured in an additional 13 patients with cirrhosis and target cells, and these data appear in Fig. 1 only. "Normals" were laboratory personnel, medical students, and house officers.

Examination of red cells. For measurement of their lipid content, red cells were thrice washed with isotonic $\mathrm{NaCl}$ and $0.2 \mathrm{ml}$ of packed red cells were extracted with $80 \mathrm{vol}$ of isopropanol and chloroform (29). Extracts were freed of nonlipid phosphorus by thrice washing with $0.05 \mathrm{M} \mathrm{KCl}$ (1/5 vol). Cholesterol (30) and lipid phosphorus (31) were measured with standard errors (95\% confidence limits) of 1.8 and $2.4 \%$, respectively. The phospholipid composition of red cells was examined by thin-layer chromatography (TLC) (32). The antioxidant 2,3-di-tert-butyl-4-methylphenol (BHT) (33) was added to lipid extracts to prevent lipid peroxidation. Chromatography was carried out on precoated Silica Gel-G TLC plates (E. Merck A. G., Darmstadt, Germany) using the chloroform: methanol:glacial acetic acid: water $(25: 15: 4: 2)$. Spots were visualized with iodine, quantitatively recovered, and digested for determination of their phosphorus content (31). Lipid phosphorus recovery from TLC plates ranged from $89-96 \%$. 
TABLE 1

Clinical Features of Patients with Severe, Chronic Liver Disease

\begin{tabular}{|c|c|c|c|}
\hline & $\begin{array}{l}\text { Normal } \\
(15)^{*}\end{array}$ & $\begin{array}{l}\text { Target cells } \\
\quad(27)^{*}\end{array}$ & $\begin{array}{l}\text { Spur cells } \\
(17)^{*}\end{array}$ \\
\hline Hematocrit, $\%$ & $43.8 \pm 2.2$ & $32.2 \pm 5.3$ & $25.2 \pm 4.3$ \\
\hline Mean cell volume, $\mu^{3}$ & $87.9 \pm 2.5$ & $96.7 \pm 11.5$ & $99.8 \pm 11.2$ \\
\hline Reticulocytes, $\%$ & $0.8 \pm 0.2$ & $3.9 \pm 1.8$ & $5.4 \pm 5.5$ \\
\hline $\begin{array}{l}\text { Serum albumin, } \\
\mathrm{g} / 100 \mathrm{ml} \\
\text { Serum bilirubin, }\end{array}$ & $4.6 \pm 0.2$ & $2.7 \pm 0.6$ & $2.5 \pm 0.6$ \\
\hline$m g / 100 m l$ & $0.8 \pm 0.2$ & $7.4 \pm 4.9$ & $12.0 \pm 6.9$ \\
\hline Prothrombin time, sec $\ddagger$ & 12.5 & $16.7 \pm 1.6$ & $20.1 \pm 3.2$ \\
\hline
\end{tabular}

* Number of subjects.

$\ddagger$ Values normalized to $12.5 \mathrm{sec}$.

Examination of serum. Serum albumin and bilirubin levels were determined in the routine hospital clinical laboratory. Plasma prothrombin times were determined in the routine clinical laboratories and, for comparison, were normalized to control values of $12.5 \mathrm{sec}$. Sera for lipid determinations were obtained in the fasting state. To obtain isolated lipoprotein fractions serum was diluted 1:1 with isotonic $\mathrm{NaCl}$ and centrifuged at $108,000 \mathrm{~g}$ in a 65 rotor in a Beckman preparative ultracentrifuge (Beckman Instruments, Inc., Palo Alto, Calif.) for $16 \mathrm{hr}$ at $4^{\circ} \mathrm{C}$. The supernatant containing very low density lipoprotein (VLDL) was discarded. The density was adjusted to 1.063 by the addition of $\mathrm{KBr}$ and the serum was centrifuged for another $24 \mathrm{hr}$ at $108,000 \mathrm{~g}$ to obtain low density lipoprotein (LDL). The density was then adjusted to 1.21 by the addition of additional $\mathrm{KBr}$ and the serum was centrifuged for $48 \mathrm{hr}$ at $108,000 \mathrm{~g}$ to obtain high density lipoprotein (HDL) (34). Lipoprotein fractions were dialyzed against three changes of isotonic $\mathrm{NaCl}$ over $24 \mathrm{hr}$ at $4^{\circ} \mathrm{C}$. Lipids of whole serum and of isolated lipoprotein fractions were extracted with acetone: ethanol $(1: 1)$ at $50^{\circ} \mathrm{C}$ for the measurement of total (30) and free cholesterol (35) and lipid phosphorus (31). The phospholipid composition was determined as for red cells (32) with the addition of BHT to lipid extracts. Protein was determined by the method of Iowry, Rosebrough, Farr, and Randall (36) and values obtained for the protein of LDL were multiplied by a factor of 0.77 to correct for the falsely high values given by this method (37). Phospholipid of both red cells and serum was taken to equal lipid phosphorus times 25 .

Measurement of LCAT. The activity of LCAT was determined by measuring the fall in the serum concentration of free cholesterol after incubation for $6 \mathrm{hr}$ at $37^{\circ} \mathrm{C}$, as previously reported (38). The hydrolysis of cholesterol esters was assessed in incubations which contained ${ }^{14} \mathrm{C}$ labeled cholesterol stearate (New England Nuclear, Boston, Mass.) in ethanol $(10 \mu \mathrm{l} / 200 \mu \mathrm{l}$ of serum $)$. Cholesterol and cholesterol esters were recovered from Silica Gel-G after TLC in ethyl acetate: benzene $(1: 5)$, and radioactivity was measured in a liquid scintillation counter (38).

Serum bile acids. Bile acids were extracted from $5 \mathrm{ml}$ of serum by the method of Grundy, Ahrens, and Miettinen (39), modified by the use of enzymatic rather than hydrolytic cleavage of bile acid conjugates (40). The trimethylsilyl derivatives of methyl bile acids were measured by gasliquid chromatography on a high efficiency $8 \mathrm{BP}$ column (Applied Science Laboratories, Inc., State College, Pa.). Recovery was measured using cholic acid ${ }^{14} \mathrm{C}$ (New England Nuclear, Boston, Mass.) and quantitation was carried out using 5 - $\beta$-cholanic acid as an internal standard. Bile acid standards for gas-liquid chromatography were obtained commercially (Supelco, Inc., Bellefonte, $\mathrm{Pa}$.) and repurified by TLC. The recovery of cholic acid- ${ }^{14} \mathrm{C}$ was $72 \pm 14 \%$. The recoveries of purified nonradioactive lithocholic acid, deoxycholic acid, and cholic acid added to saline in a concentration of $100 \mu \mathrm{g} / \mathrm{ml}$ and extracted from this solution by the above method were equivalent.

Studies in vitro. Red cells obtained from defibrinated blood were washed free of white cells in Hank's balanced salt solution. Incubations were performed in sterile, stoppered vessels in a $37^{\circ} \mathrm{C}$ atmosphere with agitation for $20-24$ $\mathrm{hr}$. During incubation under these conditions the $\mathrm{pH}$ varied from initial values of 7.5-7.6 to final values of 7.1-7.3. When red cells were incubated at cell concentrations greater than $10 \%$, glucose was added as $5 \%$ dextrose and water to raise the glucose concentration of the medium $100 \mathrm{mg} / 100$ $\mathrm{ml}$ for each $10 \%$ rise in cell concentration. Sera referred to as "heated" were heated to $56^{\circ} \mathrm{C}$ for $30 \mathrm{~min}$ to inactivate the serum enzyme LCAT.

Statistics. Unless otherwise noted, values are expressed as the mean \pm 1 SD. Regression analyses and correction coefficients were computed by the method of least squares using a Wang-500 computer (Wang Laboratories, Inc.,

TABLE II

Red Cell Phospholipid Composition

\begin{tabular}{|c|c|c|c|c|c|}
\hline & Lysolecithin & Sphingomyelin & Lecithin & Phosphatidylserine & $\begin{array}{l}\text { Phosphatidyl } \\
\text { ethanolamine }\end{array}$ \\
\hline \multicolumn{6}{|l|}{ Composition, $\%$} \\
\hline Normal $(11)^{*}$ & $1.3 \pm 0.8$ & $28.1 \pm 2.0$ & $33.2 \pm 1.1$ & $7.8 \pm 2.5$ & $29.5 \pm 0.8$ \\
\hline Target cells (14) & $1.2 \pm 1.0$ & $23.8 \pm 3.4$ & $43.4 \pm 5.5$ & $7.4 \pm 1.9$ & $24.2 \pm 2.2$ \\
\hline Spur cells (12) & $1.3 \pm 0.8$ & $25.4 \pm 3.6$ & $38.6 \pm 1.7$ & $8.7 \pm 1.9$ & $25.3 \pm 1.9$ \\
\hline \multicolumn{6}{|l|}{ Content, $\mu \mathrm{g} / 10^{8} \mathrm{cells}$} \\
\hline Normal & $0.40 \pm 0.25$ & $8.80 \pm 0.71$ & $10.39 \pm 0.34$ & $2.44 \pm 0.83$ & $9.23 \pm 0.27$ \\
\hline Target cells & $0.44 \pm 0.31$ & $8.76 \pm 1.08$ & $15.97 \pm 1.85$ & $2.72 \pm 0.63$ & $8.90 \pm 0.70$ \\
\hline Spur cells & $0.43 \pm 0.25$ & $8.42 \pm 1.20$ & $12.80 \pm 0.63$ & $2.88 \pm 0.61$ & $8.39 \pm 0.62$ \\
\hline
\end{tabular}

\footnotetext{
* Number of subjects.
} 
Tewksbury, Mass.) equipped with the Wang 500 statistical tape.

\section{RESULTS}

Clinical features. Laboratory tests which reflect the degree of anemia and hemolysis and the extent of hepatic dysfunction are shown on Table I. Anemia was more severe in patients with spur cells than in those with target cells. Hematocrits in patients with target cells ranged from 24 to $42 \%$, but two-thirds were $30 \%$ or greater. The hematocrits of patients with spur cells ranged from 19 to $30 \%$. Mean cell volumes were moderately increased over normal but were not significantly different in the two groups of patients. The per cent reticulocytes was increased in both groups of patients, although somewhat more in the patients with spur cells than those with target cells. The absolute number of reticulocytes was similar. Serum albumin was low in both groups of patients but it was not significantly different in the two groups. Serum bilirubin was elevated in the group of patients with spur cells, and, since jaundice was one of the criteria study of patients with target cells, the bilirubin was elevated in this group as well. Prothrombin times were prolonged in both groups of patients but were significantly longer in patients with spur cells than patients with target cells $(P<0.01)$. This was the only test reflecting liver function which indicated a difference between the two groups of patients.

Red cell lipids. The cholesterol and phospholipid content of red cells from these two groups of patients and an additional 13 patients with severe cirrhosis and target cells are shown in Fig. 1. Cholesterol was markedly increased in the red cells of patients with spur cells, but only in four of these patients did the content of phospholipid per red cell exceed the normal range. The free cholesterol/phospholipid (FC/PL) mole ratio of spur cells was $1.30 \pm 0.10$ (normal $=0.87 \pm 0.03$ ). Target cells were also rich in cholesterol; however, in contrast to spur cells the phospholipid content of target cells was usually increased as well. A positive correlation existed between the increment in cholesterol and the increment in phospholipid in target cells $(r=0.67 ; P<0.01)$. The slope of the regression line predicts that for each mole of phospholipid accrued by red cells there will be 1.1 moles of cholesterol accrued. The $\mathrm{FC} / \mathrm{PL}$ ratio of target cells were thereby increased to only $1.01 \pm 0.10$. The $\mathrm{FC} / \mathrm{PL}$ ratios of spur and target cells were significantly different from normal and from each other $(P<0.001)$.

An analysis of the phospholipids of red cells is shown in Table II. The mean content of phospholipid in the 14 patients with target cells and the 12 patients with spur cells whose phospholipids were analyzed was similar to the mean for the larger group of each of these
TABLE III

Serum Lipids in Liver Disease

\begin{tabular}{lccc}
\hline & $\begin{array}{c}\text { Normal } \\
(18)\end{array}$ & $\begin{array}{c}\text { Target cells } \\
(22)\end{array}$ & $\begin{array}{c}\text { Spur cells } \\
(16)\end{array}$ \\
\hline Total cholesterol, $m g / 100 m l$ & $216.6 \pm 63.8^{*}$ & $168.3 \pm 89.1$ & $242.0 \pm 100.3$ \\
Free cholesterol, $m g / 100 m l$ & $56.6 \pm 20.0$ & $81.1 \pm 39.9$ & $116.5 \pm 46.8$ \\
FC/CE*, mole $/$ mole & $0.34 \pm 0.06$ & $1.38 \pm 1.05$ & $1.12 \pm 0.72$ \\
Phospholipid, $m g / 100 m l$ & $230.2 \pm 71.1$ & $194.7 \pm 83.9$ & $228.2 \pm 77.2$ \\
FC/PL*, mole/mole & $0.48 \pm 0.15$ & $0.85 \pm 0.19$ & $1.06 \pm 0.26$ \\
\hline
\end{tabular}

* FC, free cholesterol ; CE, cholesterol esters; PL, phospholipids.

patients represented in Fig. 1. The most striking abnormality was a marked increase in the per cent lecithin in target cells and a somewhat smaller but significant increase in the per cent lecithin in spur cells. There was a reciprocal decrease in the per cent of the other major phospholipids. However, when the phospholipid composition of these red cells was expressed in absolute amounts rather than relative per cent, there was no significant difference in any of the phospholipids except for lecithin. Indeed, the increment in lecithin was similar to the increments in total phospholipid in both target cells and spur cells: in target cells the increment in phospholipid content was $5.50 \mathrm{\mu g} / 10^{8}$ and in lecithin content it was $5.58 \mu \mathrm{g} / 10^{8}$ cells; in spur cells the increment in phospholipid content was $1.85 \mu \mathrm{g} / 10^{8}$ cells and in lecithin content it was increased $2.42 \mu \mathrm{g} / 10^{8}$ cells. The mean cholesterol/lecithin mole ratio was decreased in target cells to 2.31 and increased in spur cells to 3.37 ( normal $=2.61)$.

Serum lipids. Serum lipids, measured in 16 patients with spur cells and 22 patients with target cells, are compared with the values in 18 normals in Table III. As reflected by the large SD, there was a considerable range of values for each of the lipids measured in both groups of patients. Mean values for total cholesterol were lower than normal in patients with target cells, a finding that is not uncommon in far advanced liver disease (41). This was less common in patients with spur cells, and total cholesterol was significantly higher in patients with spur than with target cells $(P<0.05)$. Serum levels of free cholesterol were increased in both

TABLE IV

Serum Phospholipids in Liver Disease

\begin{tabular}{lccc}
\hline & $\begin{array}{c}\text { Normal } \\
(4)\end{array}$ & $\begin{array}{c}\text { Target cell } \\
(9)\end{array}$ & $\begin{array}{c}\text { Spur cell } \\
(9)\end{array}$ \\
\hline Lysolecithin. \% & $7.1 \pm 2.0$ & $7.5 \pm 2.5$ & $9.0 \pm 3.9$ \\
Sphingomyelin, \% & $16.7 \pm 2.1$ & $16.7 \pm 3.2$ & $20.1 \pm 4.5$ \\
Lecithin, \% & $69.7 \pm 3.2$ & $70.0 \pm 3.5$ & $62.5 \pm 2.7$ \\
$\quad$ Range & $(67.0-735)$ & $(65.7-77.5)$ & $(59.7-65.4)$ \\
Phosphatidylserine, \% & $26 \pm 0.8$ & $2.4 \pm 0.6$ & $2.4 \pm 1.4$ \\
Phosphatidylethanolamine, \% & $3.6 \pm 0.8$ & $3.3 \pm 1.0$ & $5.8 \pm 2.6$ \\
\hline
\end{tabular}




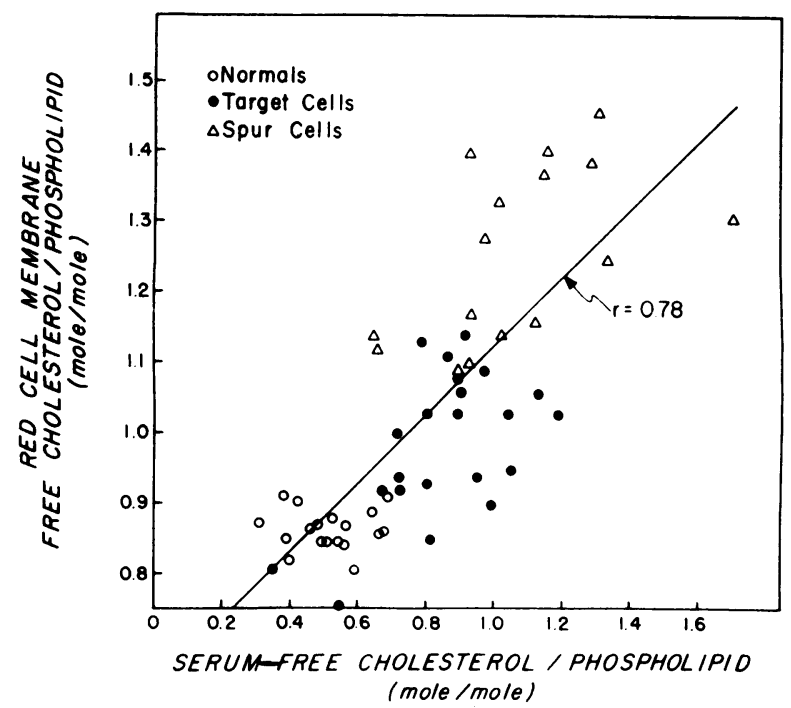

Figuke 2 The relationship between the Fic/Pl. mole ratior of serum and red cell membranes.

groups of patients: spur $>$ target $>$ normal. Serum levels of phospholipid were not signiticantly different among the three groups, and, therefore, the $\mathrm{FC} / \mathrm{Pl}$. mole ratios were increased in the same progression: spur $>$ target $>$ normal.

The per cent composition of serum pinospholipids was similar in patients with target cells and normals, although the range of values for lecithin extended to higher values in patients than normals (Table IV). The per cent lecithin in the serum of patients with spur cells was significantly lower than in normal or target cell serum $(P<0.001)$ and the range of values in the nine spur patients studied did not overlap values in the other two groups.

Relationship between serum and red cell lipids. There was no direct relationship between the serum concentration of free cholesterol and the red cell cholesterol content over a wide range of values in both groups of patients $(r=0.20)$. Likewise, a poor relationship exisited between the serum concentration of phospholipid and the red cell phospholipid content $(r=0.20)$. However, when the $\mathrm{FC} / \mathrm{PL}$ mole ratios of serum and red cell lipids were compared, a strong relationship existed $(r=0.78 ; P<0.001)$ (Fig. 2). This direct relationship was also seen when only the values obtained from patients were used in this calculation, i.e., when normal subjects were excluded $(r=0.65)$. This relationship between the $\mathrm{FC} / \mathrm{PL}$ mole ratio of serum and red cells was substantiated by two experiments in vitro.

(a) Both normal and target cells acquire cholesterol when incubated in the serum of patients with spur cells (10). The red cells of two patients with obstructive jatundice and target cells (average values: cholesterol.
$18.80 \mu \mathrm{g} / 10^{8}$ cells; phospholipid $37.25 \mu \mathrm{g} / 10^{8}$ cells ; $\mathrm{FC} / \mathrm{PL}, 1.01$ ) and two normal subjects (cholesterol $13.52 \mu \mathrm{g} / 10^{8}$ cells; phospholipid $31.30 \mu \mathrm{g} / 10^{8}$ cells; $\mathrm{FC} / \mathrm{PL}, 0.87$ ) were incubated for $24 \mathrm{hr}$ at $37^{\circ} \mathrm{C}$ at a hematocrit of $5 \%$ in the serum of a patient with spur cells (red cell $\mathrm{FC} / \mathrm{PL}=1.46$ ). During incubation there was no change in red cell phospholipid content. However, the amount of cholesterol accrued by each was sufficient to produce a $\mathrm{FC} / \mathrm{PL}$ ratio similar to the other and to the serum donor (target cells, $\mathrm{FC} / \mathrm{PL}=1.44$; normal cells, $\mathrm{FC} / \mathrm{PL}=1.43)$. Thus, although the total cholesterol content of spur, target, and normal red cells differed markedly both before and after incubation, the $\mathrm{FC} / \mathrm{PL}$ mole ratios after incubation were very similar in all three cases.

(b) Spur cells lose cholesterol when incubated in normal serum previously heated to $56^{\circ} \mathrm{C}$ for $30 \mathrm{~min}$, and this cholesterol is recovered in the lipoprotein fractions of normal serum (42). Normal red cells subsequently incubated in this serum gain free cholesterol. In four such experiments the average value for the $\mathrm{FC} / \mathrm{PI}$. mole ratio of normal serum after incubation with spur cells for $24 \mathrm{hr}$ at a hematocrit of $35 \%$ rose from an initial value of 0.53 to a final value of 0.78 . From the data in Fig. 2 it can be calculated that normal red cells incubated in serum with a $\mathrm{FC} / \mathrm{PL}$ of 0.78 would gain an amount of free cholesterol sufficient to raise their membrane $\mathrm{FC} / \mathrm{PL}$ mole ratio to 1.03 . The $\mathrm{FC} / \mathrm{PL}$ mole ratio measured in these normal cells after incubation was 1.06 ( range $=1.04-1.08$ ).

Analysis of serum lipoproteins. The relative amounts of free cholesterol, phospholipid, and protein in LDI and HDI, were analyzed (Table V). The FC/PL mole

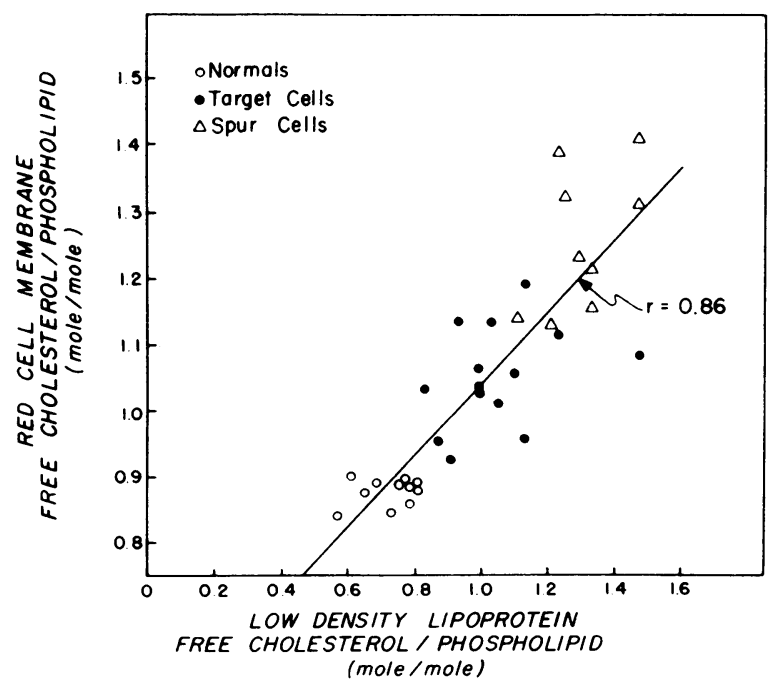

Figuke 3 The relationship between the $\mathrm{FC} / \mathrm{PL}$ mole ratio of LDL and red cell membranes. 
ratio of LDL in patients with target cells was signiticantly greater than normal $(P<0.001)$, and this ratio in patients with spur cells was significantly greater than in patients with target cells $(P<0.001)$. The free cholesterol/protein ratio (FC/Prot) (w/w) of LDL followed a similar progression: spur patients $>$ target patients $>$ normal $(P<0.001)$. Although the phospholipid/protein ratio (PL/Prot) (w/w) of LDL in patients with target cells was significantly greater than that in normals, there was no significant difference between the PL/Prot ratio of LDL from patients with target and spur cells. HDL also had greater ratios of FC/PL, FC/Prot, and PL/Prot in the serum of patients with liver disease than in normals; however, these were not significantly different in patients with target cells and spur cells.

Figs. 3 and 4 show the relationship between the free cholesterol saturation of LDL, as defined by its $\mathrm{FC} /$ $\mathrm{PL}$ and $\mathrm{FC} /$ Prot ratios, and the $\mathrm{FC} / \mathrm{PL}$ mole ratio of red cell membranes. A close correlation existed in both instances. This relationship was particularly strong between the FC/Prot ratio of LDL and the FC/PL ratio of red cell membranes $(r=0.94)$. Good correlations with red cell $\mathrm{FC} / \mathrm{PL}$ also existed when only the values from patients were used in this calculation (LDL FC/PL, $r=0.66$; LDL FC/Prot, $r=0.90$ ). Direct relationships such as those described for LDL did not exist between HDL and the FC/PL of red cell membranes.

Serum LCAT activity. The LCAT of serum was assayed in 19 patients with target cells and 9 patients with spur cells. The value of LCAT in 20 normals was $26.8 \pm 6.2 \mu \mathrm{g}$ of cholesterol esterified per $\mathrm{ml}$ of serum per hr during the $6 \mathrm{hr}$ incubation used to assess the activity of this enzyme. This value is similar to that reported for normals previously: $21.9 \mu \mathrm{g}$ (24), $24.8 \mu \mathrm{g}$ (43), and $27.6 \mu \mathrm{g}$ (25). Also consistent with previous reports is the wide variation among normals. The mean value for LCAT was $10.8 \pm 9.1 \mu \mathrm{g}$ of cho-

TABLE $\mathrm{V}$

Composition of Serum Lipoproteins in Liver Disease

\begin{tabular}{lccc}
\hline & $\begin{array}{c}\text { Free } \\
\text { cholesterol } \\
\text { phospholipid }\end{array}$ & $\begin{array}{c}\text { Free } \\
\text { cholesterol } \\
\text { protein }\end{array}$ & $\begin{array}{c}\text { Phospholipid } \\
\text { protein }\end{array}$ \\
\hline & mole/mole & $w / w$ & $w / w$ \\
Low density lipoprotein & & & \\
Normal cell (13) & $0.72 \pm 0.08$ & $0.37 \pm 0.07$ & $0.79 \pm 0.08$ \\
Target cells (13) & $1.04 \pm 0.16$ & $0.67 \pm 0.12$ & $1.00 \pm 0.12$ \\
Spur cells (9) & $1.28 \pm 0.12$ & $0.92 \pm 0.18$ & $1.11 \pm 0.13$ \\
High density lipoprotein & & & \\
Normal cell (8) & $0.15 \pm 0.08$ & $0.06 \pm 0.03$ & $0.61 \pm 0.16$ \\
Target cells (12) & $0.56 \pm 0.15$ & $0.26 \pm 0.10$ & $0.89 \pm 0.15$ \\
Spur cells (5) & $0.59 \pm 0.23$ & $0.27 \pm 0.11$ & $0.91 \pm 0.26$ \\
\hline
\end{tabular}

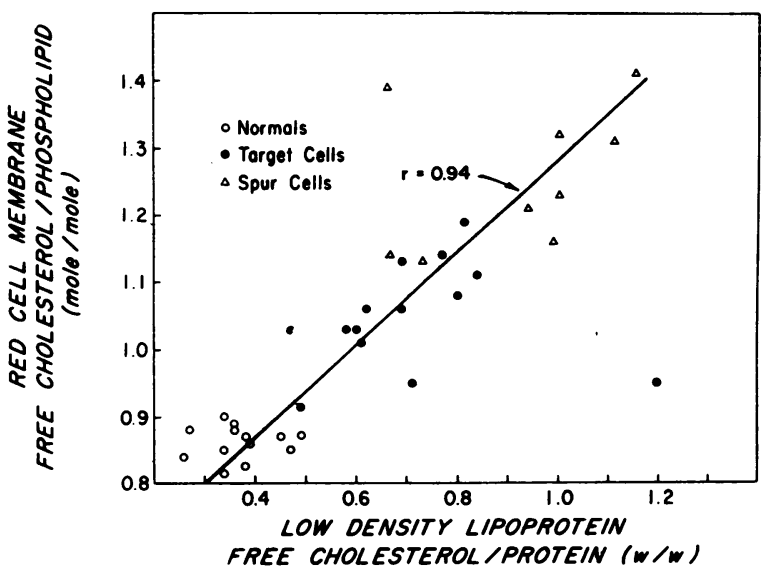

FIGURE 4 The relationship between the $\mathrm{FC} /$ Prot weight ratio of $\mathrm{LDL}$ and the $\mathrm{FC} / \mathrm{PL}$ mole ratio of red cell membranes. The two points distant from the curve were greater than 2 SD from the remainder of the data and were excluded from the regression analysis.

lesterol esterified per $\mathrm{ml}$ of serum per $\mathrm{hr}$ in patients with target cells and $6.2 \pm 5.7 \mu \mathrm{g}$ in patients with spur cells.

There was a poor correlation between the activity of LCAT and the red cell content of cholesterol $(r=0.32)$ (Fig. 5). A similar correlation coefficient $(r=0.31)$ was obtained when LCAT activity was compared with the $\mathrm{FC} / \mathrm{PL}$ mole ratio of target cells and spur cells. However, both correlation coefficients statistically were significant $(P<0.05)$.

The ability of serum to hydrolyze cholesterol esters and thereby mask the simultaneous esterification of cholesterol by LCAT was assayed using ${ }^{14} \mathrm{C}$-labeled cholesterol stearate in 16 of the 28 patients in this study (13 with target cells, 3 with spur cells). In none of these 16 patients, nor in two normals studied, was there any measurable hydrolysis of cholesterol esters during 24 $\mathrm{hr}$ of incubation at $37^{\circ} \mathrm{C}$.

Serum bile acids. Serum bile acids were measured in 21 patients with target cells and 13 patients with spur cells. The mean value for total serum bile acid in four normal subjects was $3.9 \pm 0.5 \mu \mathrm{g} / \mathrm{ml}$. Total bile acids ranged from $5.6 \mu \mathrm{g} / \mathrm{ml}$ to $125.6 \mu \mathrm{g} / \mathrm{ml}$ in patients with liver disease (Fig. 6). The mean value in patients with target cells was $31.9 \mu \mathrm{g} / \mathrm{ml}$ and in patients with spur cells it was $44.1 \mu \mathrm{g} / \mathrm{ml}$; this difference is not significant $(P<0.05)$. There was also no significant correlation between the serum concentration of bile acids and e.ther the red cell content of cholesterol or the red cell $\mathrm{FC} / \mathrm{PL}$ mole ratio.

The predominant bile acids in serum were chenodeoxycholic and cholic acids, only small amounts of deoxycholic acid being found in most patients. A peak that coincided with the trifluoroacetate derivative of standard 


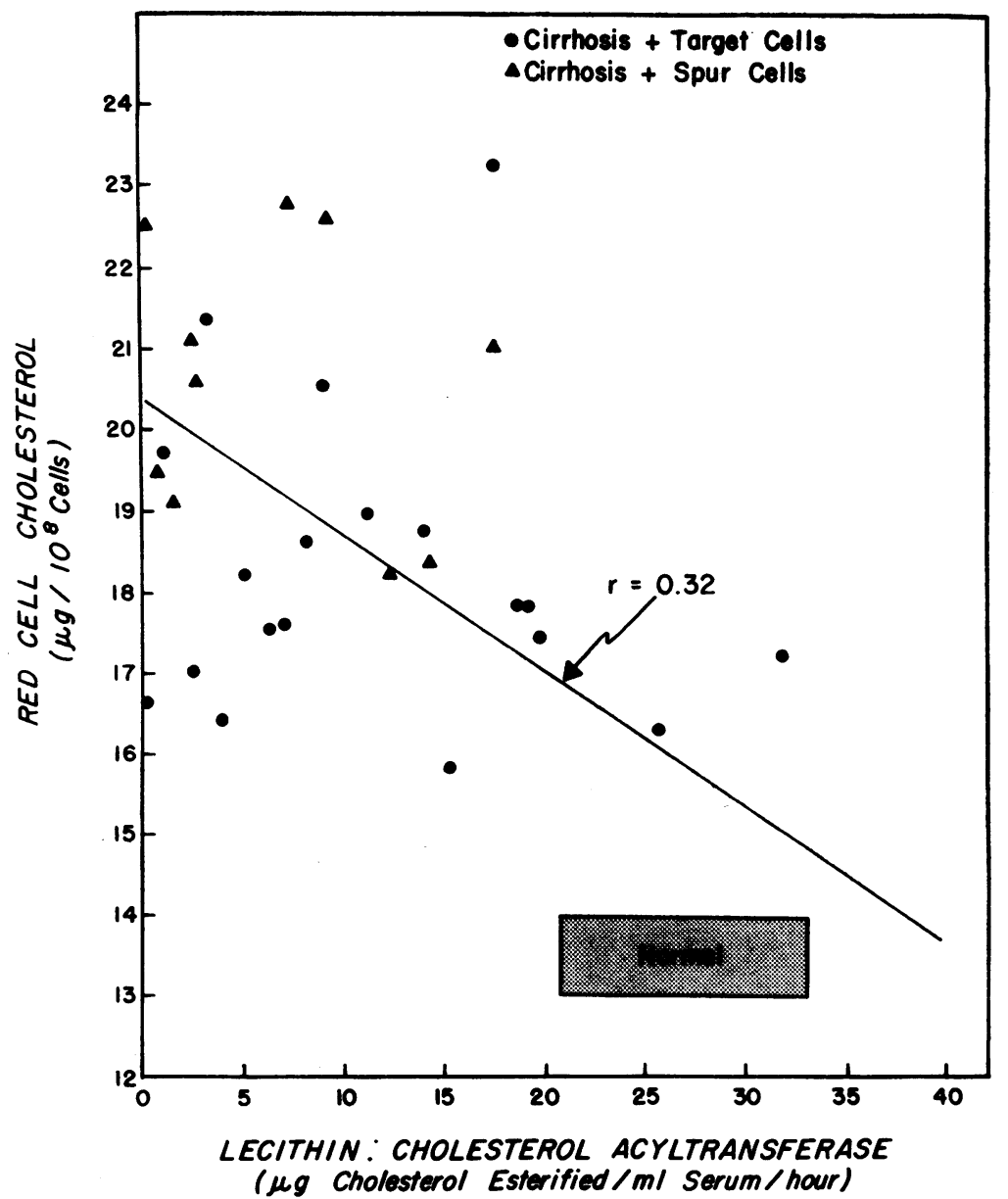

FIGURE 5 The relationship between LCAT activity and red cell cholesterol. Mean \pm SD for 20 normals is shown.

methyl-lithocholate was present in many patients. This peak was interpreted as lithocholic acid in data reported by us in a previous publication (10). However, when the trimethylsilyl derivative of methyl-lithocholate was analyzed, this material was determined not to be lithocholic acid, and no measurable lithocholic acid was found in any of these patients when measured by the latter method. Re-examination of serum from patients 1 and 2 in reference 10 also revealed no measurable lithocholic acid.

The bile acid composition of serum varied significantly between the two groups of patients studied. Since deoxycholic acid is derived from cholic acid by the action of intestinal bacteria, these two bile acids were considered together and compared with chenodeoxycholic acid, the precursor of lithocholic acid (Fig. 6). Patients with target cells had higher ratios of deoxycholic + cholic acids/chenodeoxycholic acid than those with spur cells. The mean value in the group of patients with target cells was just under 1.0, whereas in patients with spur cells it was 0.28 .

\section{DISCUSSION}

The following general conclusions can be made from these studies: $(a)$ the cholesterol and phospholipid content and the cholesterol/phospholipid (or cholesterol/ lecithin) mole ratio of red cell membranes effectively distinguishes target cells from spur cells. (b) The cholesterol/phospholipid mole ratio of both types of abnormal red cells correlates closely with the free cholesterol saturation of serum lipoproteins (as defined by the amount of free cholesterol relative to phospholipid and protein in the lipoproteins). (c) In contrast to target cells, spur cells have little or no excess lecithin, and the per cent of lecithin relative to other phospholipids in serum is less in patients with spur than with target cells. $(d)$ Only a weak relationship between LCAT activity and red cell lipid content can be demon- 
strated, suggesting that LCAT deficiency may play only a minor role in the genesis of red cell lipid abnormalities in liver disease. (e) Serum bile acid levels in patients with cirrhosis correlate poorly with the lipid abnormalities observed; however, in patients with target cells the amount of cholic acid plus deoxycholic acid is approximately equal to the amount of chenodeoxycholic acid, whereas in patients with spur cells chenodeoxycholic acid (the precursor of lithocholic acid) predominates.

Red cell lipid content. The target cell phenomenon in liver disease is acquired and reversible, and changes in membrane cholesterol correlate with changes in osmotic resistance and membrane surface area in vivo and in vitro $(11,12,44,45)$. This is true in patients with many target cells as well as patients whose broad, thin red cells form only occasional targets on dried smears (45). Therefore, the per cent target cells was not used as a criterion in the group of patients studied. Cholesterolrich spur cells could be differentiated from target cells, which were rich in both cholesterol and lecithin; but whether these lipid differences are responsible for the morphologic differences remains uncertain. However, it is of interest that acanthocytes in abetalipoproteinemia also have an increased cholesterol: lecithin ratio (because of decreased lecithin) and they are morphologically indistinguishable from spur cells (38).
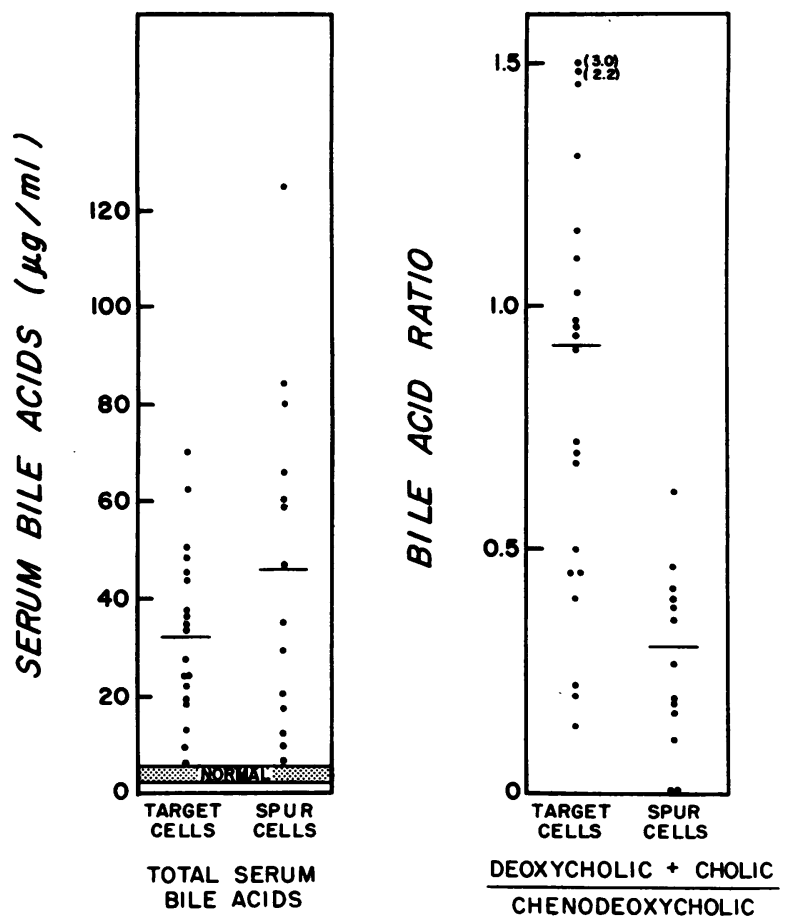

Figure 6 Serum bile acids in liver disease. Total bile acids were similar in the two groups (left); however, the relative amounts of the various bile acids differed (right).

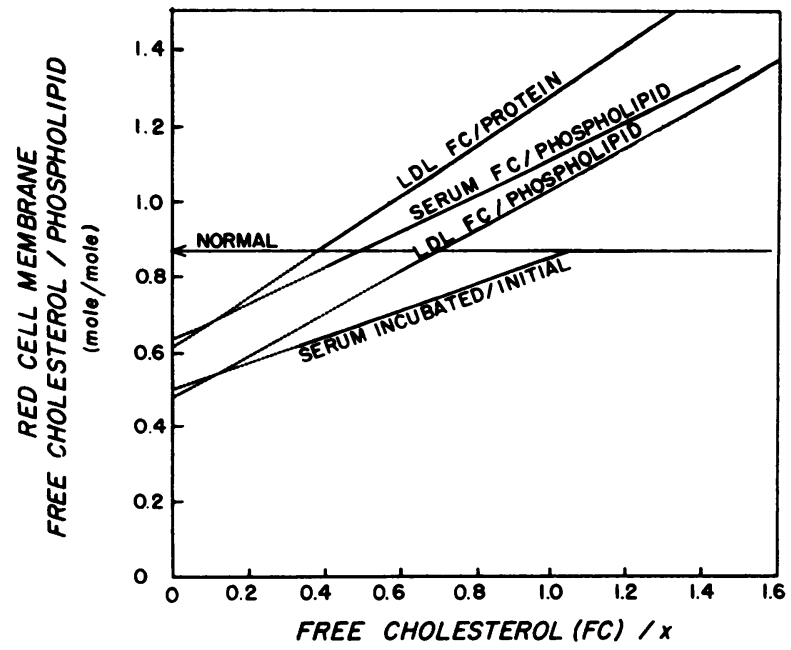

FIGURE 7 Extrapolation of observed relationships between the FC/PL mole ratio of red cell membranes and free cholesterol of serum analyzed as $\mathrm{FC} / \mathrm{PL}$ of serum (Fig. 2), FC/PL of LDL (Fig. 3), FC/Prot of LDL (Fig. 4), and FC of normal serum before and after incubation for 24 $\mathrm{hr}$ with normal red cells. Data for this latter analysis, reflecting the effect of LCAT, have been reported previously $(12,42,55)$, and the correlation coefficient for the regression line shown is $0.80(P<0.001)$. Solid lines represent the region of measured values; dotted lines represent extrapolations of these lines. In each case extrapolation of the existing relationship to a zero value for serum-free cholesterol intersected a red cell membrane $\mathrm{FC} / \mathrm{PL}$ mole ratio of $0.48-0.63$.

Relation between red cell lipids and serum lipoproteins. Red cell cholesterol behaves as a single pool which exchanges with serum-free cholesterol (46). Although data exist to the contrary (24), the studies reported herein confirm our previous observations (42) and those of Simon in patients with cirrhosis (47) and demonstrate that no correlation exists between the serum concentration and red cell content of free cholesterol. However, a close relationship was seen between red cell and serum(or isolated LDL) free cholesterol when each was considered relative to phospholipid or when LDL-free cholesterol was considered relative to protein.

Serum lecithin accumulates in patients with various types of liver disease but this accumulation is least in patients with far advanced cirrhosis (48-50). The per cent lecithin in the serum of patients with target cells reported herein was not significantly different from normal, and in patients with spur cells it was less than normal. Moreover, no correlation was seen between serum and cell phospholipid. Thus, the mechanism of lecithin accumulation in the red cell membranes is unclear. It may relate to specific species of lecithin, since only portions of the phospholipid present in red cell membranes exchange with their counterparts in serum (18, $51-53)$. 
The data in Figs. 2-4 reflect the contribution of serum lipoproteins to red cell cholesterol in the range extending from a normal to greater than normal saturation of serum lipoproteins with free cholesterol. Changes in the opposite direction occur when serum-free cholesterol is esterified by LCAT in vitro. This produces lipoproteins which have a decreased free cholesterol saturation. Red cells incubated with these lipoproteins lose cholesterol $(54,55)$. The parallel decrease in serum-free cholesterol and red cell cholesterol as influenced by LCAT in vitro is shown in Fig. 7.

Since red cell-free cholesterol exchanges completely with serum-free cholesterol, a zero value for membrane $\mathrm{FC} / \mathrm{PL}$ must exist at a zero concentration of free cholesterol in serum. If the free cholesterol saturation of serum lipoproteins is the only component which correlates with the $\mathrm{FC} / \mathrm{PL}$ of red cell membranes, the regression analyses in Figs. 2-4 (replotted in Fig. 7) and that for LCAT in Fig. 7 should interecept zero values for red cell cholesterol when they are extrapolated to a zero value for serum-free cholesterol. However, these regression lines do not pass through the origin (Fig. 7), and values for the red cell $\mathrm{FC} / \mathrm{PL}$ mole ratio defined by these intercepts are $0.63,0.62,0.50$, and 0.48 (mean $=0.56$ ). Thus, a second component describing the relation between serum and cell FC/PL must exist. This second component may represent a basal or essential amount of free cholesterol avidly held by the membrane and under little or no influence by serum lipoproteins, and it may serve important structural and functional roles in the membrane. The portion of membrane-free cholesterol in excess of this basic core appears to be closely related to the free cholesterol saturation of serum lipoproteins. That this excess may be less impotrant in specific membrane functions is suggested by the lack of change in the membrane permeability to sodium or to water when the cholesterol content of red cell membranes is decreased by LCAT (54-56), or increased by incubation in sera from patients with liver disease (57). However, this excess free cholesterol serves an important role in extending the surface area of red cells to accommodate changes in cell shape (57).

Serum LCAT activity. Decreased LCAT activity has previously been described in patients with liver disease $10,12,23-25,43)$. The level of enzymatic activity has rarely been as low as that reported in patients with the familial enzyme deficiency (58-60), and the mean values in liver disease have tended to be approximately $50 \%$ of normal. Nonetheless, it has been suggested by ourselves (61) and others (47) that LCAT deficiency may be responsible in large part for the increased amount of cholesterol and lecithin in the red cells of these patients. However, this suggestion is not supported by current data: (a) The correlation between LCAT activity and either the red cell content of cholesterol (Fig. 5) or the FC/PL mole ratio of red cells was very poor. (b) The mean level of LCAT activity was lowest in patients with spur cells; however, unlike patients with familial LCAT deficiency, only red cell cholesterol was increased, and there was little or no change in the red cell content of lecithin in these patients. (c) Recent studies in both beta lipoprotein deficiency (38) and alpha lipoprotein de ficiency ${ }^{2}$ have demonstrated a $50-75 \%$ decrease in LCAT activity without accompanying increases in red cell cholesterol or lecithin content. Thus, although LCAT deficiency may play some role in the changes observed in red cells of patients with liver disease. this role does not appear to be great.

Serum bile acids. Levels of total serum bile acids in this series of patients were similar to those previously reported for patients with cirrhosis $(27,68)$, and levels observed in normal subjects were also similar to previously reported values $(28,62-64)$. Free and conjugated bile acids were not distinguished. The precise contribution of increased serum bile acid concentration to changes in red cell and serum lipids described above is not entirely clear. Although studies in vitro have shown a direct effect of bile acids on both red cell cholesterol content (12) and on LCAT activity $(12,65,66)$, this was seen only with concentrations of bile acids 10 - to 20 -fold higher than the concentartions found in this group of patients. However, an indirect effect of bile acids may exist through their influence on cholesterol and lecithin synthesis $(67,68)$.

Serum bile acids have been analyzed previously in terms of the ratio of dihydroxy bile acids to trihydroxy bile acids $(27,69)$. Since only small amounts of deoxycholic acid are found in most patients with cirrhosis (62), the previously reported dihydroxy/trihydroxy bile acid ratios reflect to a certain extent the ratios reported herein. This ratio tends to be approxinately 1.0 in patients with hepatocellular disease and higher in patients with extrahepatic biliary obstruction $(27,28,62,69)$. However, patients with spur cells had a low ratio of deoxycholic + cholic acids/chenodeoxycholic acid. the mean value being 0.28 .

The predominance of chenodeoxycholic acid in patients with spur cells is of particular interest, since chenodeoxycholic acid is converted to lithocholic acid by colonic bacteria. Lithocholic acid is a toxic bile acid (70-73) which. when fed to rhesus monkeys, induces both spur cells and hepatocellular injury (26). Lithocholic acid was not found in the small amounts of patient's serum extracted for bile acid determinations. However, using large amounts of serum, Carey has demonstrated very small amounts of lithocholic acid in normal sera and larger amounts in sera rich in chenodeoxycholic acid (74).

${ }^{2}$ Nichols, A. V., and Levy R. I. Personal communication. 


\section{ACKNOWLEDGMENTS}

The authors are grateful to Doctors W. B. Castle and T. Warthin of the West Roxbury Veterans Administration Hospital, Boston, Mass. for referring a patient with spur cells. They are also grateful to Mrs. Barbara Thompson Good, Mrs. Margo Lawless, and Mrs. Birgit Blythe for their technical assistance and to Mrs. Susan Horgan for preparing this manuscript.

These studies were supported by U. S. Public Health Service grants AM 05391, HE 07652, FR 76, AM 15441, and AM 05228.

\section{REFERENCES}

1. Jandl, J. H., and A. A. Lear. 1956. The metabolism of folic acid in cirrhosis. Ann. Intern. Med. 45: 1027.

2. Herbert, V., R. Zalusky, and C. S. Davidson. 1963. Correlation of folate deficiency with alcoholism and associated macrocytosis, anemia, and liver disease. Ann. Intern. Med. 58: 977.

3. Sullivan, L. W., and V. Herbert. 1964. Suppression of hematopoiesis by ethanol. J. Clin. Invest. 43: 2048.

4. Kimber, C., D. J. Deller, R. N. Ibbotson, and H. Lander. 1965. The mechanism of anaemia in chronic liver disease. Q. J. Med. $34: 33$.

5. Eichner, E. R., and R. S. Hillman. 1971. The evolution of anemia in alcoholic patients. Am. J. Med. 50: 218.

6. Kilbridge, T. M., and P. Heller. 1969. Determinants of erythrocyte size in chronic liver disease. Blood $J$. Hematol. 34 : 739.

7. Jandl, J. H. 1955. The anemia of liver disease: observations on its mechanisms. J. Clin. Invest. 34: 390.

8. Smith, J. A., E. T. Lonergan, and K. Sterling. 1964. Spur-cell anemia: hemolytic anemia with red cells resembling acanthocytes in alcoholic cirrhosis. N. Engl. J. Med. 271: 396.

9. Silber, R., E. Amorosi, J. Lhowe, and H. J. Kayden. 1966. Spur-shaped erythrocytes in Laennec's cirrhosis. N. Engl. J. Med. 275 : 639.

10. Cooper, R. A. 1969. Anemia with spur cells: a red cell defect acquired in serum and modified in the circulation. J. Clin. Invest. 48: 1820.

11. Brun, G. C. 1939. Cholesterol content of the red blood cells in man. Acta Med. Scand. Suppl. 99: 1.

12 Cooper, R. A., and J. H. Jandl. 1968. Bile salts and cholesterol in the pathogenesis of target cells in obstructive jaundice. J. Clin. Invest. $47: 809$.

13. McBride, J. A., and H. S. Jacob. 1968. Cholesterol loading of acanthocytic red cell membranes causing hemolytic anemia in experimental and genetic abetalipoproteinemia. J. Clin. Invest. 47: 67a. (Abstr.)

14. Sterling, K., H. G. Rose, J. A. Smith, and E. T. Lonergan. 1964. Abnormal erythrocyte cholesterol accumulation in spur cell anemia. J. Clin. Invest. 43: 1235. (Abstr.)

15. Nye, W. H. R., and G. V. Marinetti. 1967. Alterations in erythrocyte phospholipids produced by environmental change. Proc. Soc. Exp. Biol. Med. 125: 1220.

16. Neerhout, R. C. 1968. Abnormalities of erythrocyte stromal lipids in hepatic disease. J. Lab. Clin. Med. 71 : 438.

17. Hagerman, J. S., and R. G. Gould. 1951. The in vitro interchange of cholesterol between plasma and red cells. Proc. Soc. Exp. Biol. Med. 78: 329.
18. Reed, C. F. 1968. Phospholipid exchange between plasma and erythrocytes in man and the dog. J. Clin. Invest. $47: 749$.

19. Switzer, S. 1967. Plasma lipoproteins in liver disease. I. Immunologically distinct low-density lipoproteins in patients with biliary obstruction. J. Clin. Invest. 46: 1855.

20. Papadopoulos, N. M., and M. A. Charles. 1970. Serum lipoprotein patterns in liver disease. Proc. Soc. Exp. Biol. Med. 134 : 797.

21. Glomset, J. A. 1968. The plasma lecithin: cholesterol acyltransferase reaction. J. Lipid Res. 9: 155.

22. Gjone, E., H. Torsvik, and K. R. Norum. 1968. Familial plasma cholesterol ester deficiency. A study of the erythrocytes. Scand. J. Clin. Lab. Invest. 21: 327.

23. Turner, K. B., G. H. McCormack, Jr., and A. Richards. 1953. The cholesterol-esterifying enzyme of human serum. I. In liver disease. J. Clin. Invest. 32: 801.

24. Gjone, E., and K. R. Norum. 1970. Plasma lecithincholesterol acyltransferase and erythrocyte lipids in liver disease. Acta Med. Scand. 187: 153.

25. Simon, J. B., and R. Scheig. 1970. Serum cholesterol esterification in liver disease. Importance of lecithincholesterol acyltransferase. N. Engl. J. Med. 283: 841 .

26. Cooper, R. A., F. A. Garcia, and C. Trey. 1972. The effect of lithocholic acid on red cell membranes in vivo. J. Lab. Clin. Med. 79: 7.

27. Rudman, D., and F. E. Kendall. 1957. Bile acid content of human serum. I. Serum bile acids in patients with hepatic disease. J. Clin. Invest. 36: 530.

28. Makino, I., S. Nakagawa, and K. Mashimo. 1969. Conjugated and unconjugated serum bile acid levels in patients with hepatobiliary diseases. Gastroenterology. 56: 1033 .

29. Rose, H. G., and M. Oklander. 1965. Improved procedure for the extraction of lipids from human erythrocytes. J. Lipid Res. 6: 428.

30. Zlatkis, A., B. Zak, and A. J. Boyle. 1953. A new method for the direct determination of serum cholesterol. J. Lab. Clin. Med. 41 : 486.

31. Bartlett, G. R. 1959. Phosphorus assay in column chromatography. J. Biol. Chem. 234: 466.

32. Skipski, V. P., R. F. Peterson, and M. Barclay. 1964. Quantitative analysis of phospholipids by thin-layer chromatography. Biochem. J. $90: 374$.

33. Dodge, J. T., H. Cohen, H. J. Kayden, and G. B. Phillips. 1967. Peroxidative hemolysis of red blood cells from patients with abetalipoproteinemia (acanthocytosis). J. Clin. Invest. $46: 357$.

34. Havel, R. J., H. A. Eder, and J. H. Bragdon. 1955. The distribution and chemical composition in ultracentrifugally separated lipoproteins in human serum. J. Clin. Invest. $34: 1345$.

35. Brown, H. H., A. Zlatkis, B. Zak, and A. J. Boyle. 1954. Rapid procedure for determination of free serum cholesterol. Anal. Chem. 26: 397.

36. Lowry, O. H., N. J. Rosebrough, A. L. Farr, and R. J. Randall. 1951. Protein measurement with the Folin phenol reagent. J. Biol. Chem. 193: 265.

37. Margolis, S., and R. G. Langdon. 1966. Studies on human serum $\beta_{1}$-lipoprotein. I. Amino acid composition. J. Biol. Chem. 241 : 469.

38. Cooper, R. A., and C. L. Gulbrandsen. 1971. The relationship between serum lipoproteins and red cell membranes in abetalipoproteinemia: deficiency of lecithin: cholesterol acyltransferase. J. Lab. Clin. Med. 78: 323. 
39. Grundy, S. M., E. H. Ahrens, Jr., and T. A. Miettinen. 1965. Quantitative isolation and gas-liquid chromatographic analysis of total fecal bile acids. J. Lipid Res. 6: 397.

40. Nair, P. P., and C. Garcia. 1969. A modified gas-liquid chromatographic procedure for the rapid determination of bile acids in biological fluids. Anal. Biochem. 29: 164.

41. Switzer, S. 1967. Plasma lipoproteins in the differential diagnosis of liver disease. Gastroenterology. 53: 790.

42. Cooper, R. A., and J. H. Jandl. 1969. Red cell cholesterol content: a manifestation of the serum affinity for free cholesterol. Trans. Assoc. Am. Physicians Phila. 82: 324.

43. Calandra, S., M. J. Martin, and N. McIntyre. 1971. Plasma lecithin: cholesterol acyltransferase activity in liver disease. Eur. J. Clin. Invest. 1 : 352.

44. Barrett, A. M. 1938. A special form of erythrocytepossessing increased resistance to hypotonic salt. $J$. Pathol. Bacteriol. 46: 603.

45. Werre, J. M., P. W. Helleman, M. C. Verloop, and J. De Gier. 1970. Causes of macroplania of erythrocytes in diseases of the liver and biliary tract with special reference to leptocytosis. Br. J. Haematol. 19: 223.

46. Quarfordt, S. H., and H. L. Hilderman. 1970. Quantitation of the in vitro free cholesterol exchange of human red cells and lipoproteins. J. Lipid Res. 11: 528.

47. Simon, J. B. 1971. Red cell lipids in liver disease: relationship to serum lipids and to lecithin-cholesterol acyltransferase. J. Lab. Clin. Med. $77: 891$.

48. Phillips, G. B. 1960. The lipid composition of serum in patients with liver disease. J. Clin. Invest. 39: 1639.

49. Kunz, F., and D. Kosin. 1970. Plasma phospholipids in cirrhosis of liver and fatty liver. Clin. Chim. Acta. 27 : 185.

50. Gjone, E., and O. M. Orning. 1966. Plasma phospholipids in patients with liver disease. A quantitative thin layer chromatographic study. Scand. J. Clin. Lab. Invest. Suppl. 18: 209.

51. Shohet, S. B., and D. G. Nathan. 1970. Incorporation of phosphate precursors from serum into erythrocytes. Biochim. Biophys. Acta. 202: 202.

52. Tarlov, A. R., and E. Mülder. 1967. Phospholipid metabolism in rat erythrocytes: quantitative studies of lecithin biosynthesis. Blood J. Hematol. 30: 853. (Abstr.)

53. Shohet, S. B. 1970. Release of phospholipid fatty acid from human erythrocytes. J. Clin. Invest. 49: 1668.

54. Murphy, J. R. 1962. Erythrocyte metabolism. III. Relationship of energy metabolism and serum factors to the osmotic fractability following incubation. $J$. Lab. Clin. Med. 60: 86

55. Cooper, R. A., and J. H. Jandl. 1969. The selective and conjoint loss of red cell lipids. J. Clin. Invest. 48: 906.

56. Sha'afi, R. I., C. Gary-Bobo, and A. K. Solomon. 1969. Cholesterol effect on hydraulic conductivity of red cell membranes. Biochim. Biophys. Acta. 173: 141.

57. Cooper, R. A., and J. H. Jandl. 1969. The role of membrane lipids in the survival of red cells in hereditary spherocytosis. J. Clin. Invest. $48: 736$.

58. Torsvik, H. 1969. Presence of $\alpha_{1}$-lipoprotein in patients with familial plasma lecithin: cholesterol acyltransferase deficiency. Scand. J. Clin. Lab. Invest. 24: 187.

59. Hamnström, B., E. Gjone, and K. R. Norum. 1969. Familial plasma lecithin: cholesterol acyltransferase deficiency. Br. Med. J. 2: 283.

60. Norum, K. R., S. Borsting, and I. Grundt. 1970. Familial lecithin: cholesterol acyltransferase deficiency. Study of two new patients and their close relatives. Acta Mcd. Scand. 188: 323 .

61. Cooper, R. A., and J. H. Jandl. 1966. Mechanism of "target cell" formation in jaundice. Clin. Res. 14: 314. (Abstr.)

62. Sandberg, D. H., J. Sjövall, K. Sjövall, and D. A. Turner. 1965. Measurement of human serum bile acids by gas-liquid chromatography. J. Lipid Res. 6: 182.

63. Rautureau, P. M., B. Chevrel, and J. Caroli. 1967. Les acides biliaires sanguins en hepatologie. II. Les cirrhoses du foie. Rev. Med. Chir. Mal. Foie Rate Pancrease. $42: 173$.

64. Carey, J. B. Jr., I. D. Wilson, F. G. Zaki, and R. F Hanson. 1966. The metabolism of bile acids with special reference to liver injury. Medicine (Baltimore). 45: 461.

65. Sperry, W. M. 1935. Cholesterol esterase in blood. J. Biol. Chem. $111: 467$.

66. Jones, D. P., F. R. Sosa, J. Shartsis, P. T. Shah, E. Skromak, and W. T. Beher. 1971. Serum cholesterol esterifying and cholesteryl ester hydrolyzing activities in liver diseases: relationships to cholesterol, bilirubin, and bile salt concentrations. J. Clin. Invest. 50: 259.

67. Weis, H. J., and J. M. Dietschy. 1969. Failure of bile acids to control hepatic cholesterogenesis: evidence for endogenous cholesterol feedback. J. Clin. Invest. 48: 2398.

68. Balint, J. A., D. A. Beeler, E. C. Kyriakides, and D. H Treble. 1971. The effect of bile salts upon lecithin synthesis. J. Lab. Clin. Med. 77: 122.

69. Carey, J. B., Jr. 1958. The serum trihydroxy-dihydroxy bile acid ratio in liver and biliary tract diseases. $J$. Clin. Invest. 37 : 1494.

70. Hunt, R. D., G. A. Leveille, and H. E. Sauberlich. 1963. Dietary bile acids and lipid metabolism. II. The ductular cell reaction induced by lithocholic acid. Proc. Soc. Exp. Biol. Med. 113 : 139.

71. Edwards, H. M. Jr., and F. M. Boyd. 1963. Action of lithocholic acid in the germ free chick. Proc. Soc. Exp. Biol. Med. 113: 294.

72. Hunt, R. D. 1965. Proliferation of bile ductules (the ductular cell reaction) induced by lithocholic acid. Fed. Proc. $24: 431$

73. Kappas, A., and R. H. Palmer. 1963. Selected aspects of steroid pharmacology. Pharmacol. Rev. 15: 123.

74. Carey, J. B., Jr., and G. Williams. 1965. Lithocholic acid in human-blood serum. Science (Wash. D. C.). $150: 620$. 